\title{
The Other Way Around: The Roma Minority's View on Doing Research on Sensitive Topics
}

\author{
Simon Wallengren ${ }^{1}$, Caroline Mellgren ${ }^{1}$ \\ ${ }^{1}$ Malmö University, Malmö, Sweden \\ Correspondence: Caroline Mellgren, Malmö University, Faculty of health and society. 20506 Malmö, Sweden.
}

Received: March 19, 2015

Accepted: April 7, 2015

Available online: May 19, 2015

doi:10.11114/ijsss.v3i4.731

URL: http://dx.doi.org/10.11114/ijsss.v3i4.731

\begin{abstract}
The object of this study was to identify strategies for successfully studying ethnic minority groups, with a special focus on the Roma minority. Some ethnic minorities are hard to reach and have a low level of participation in research, particularly when it involves sensitive questions such as victimization experiences. This is problematic since difficulties accessing a group for research purposes may result in a lack of research; in turn leading to a knowledge gap concerning some groups lived experiences. Based on interviews with members of the Roma community we identitied difficulties related to gaining access to the population for research purposes. Results show that researchers studying minorities need to gain cultural understanding and competence.
\end{abstract}

Keywords: qualitative, sensitive questions, minorities, Roma

\section{Introduction}

Overall, there is recognition among researchers in various fields investigating sensitive topics that this kind of research may be demanding, both methodologically and personally. If research is conducted on hard-to-reach minority populations the barriers are many and strategies to address these problems are needed (for a recent review of the literature regarding research with disadvantaged groups, see Bonevski et.al., 2014). Much research has been concerned with researchers experiences of being in the field and many of the challenges faced by researchers are related to ethical concerns, such as not getting too close to the interviewees or handling the emotions caused by discussing sensitive topics (Higgins, 1998). For example, in an interview study with 30 health researchers Dickson-Swift et.al (2007) found that researchers struggle with, among other things, gaining the informant's confidence and listening to untold stories, feelings of vulnerability, and mental and physical exhaustion. Few focus, however, on the research process from the study subject's point of view. The Roma minority is one of Europe's most discriminated minorities. Past and current discrimination and victimization of the Roma minority in Sweden has resulted in a lack of confidence in the majority society in general and the criminal justice system in particular. The situation of the Roma minority in Sweden has been called "...unworthy of a democratic society as ours" (SOU 2010, p. 204). Crimes targeting minorities in Sweden are, according to official figures, on the rise (Aspling \& Djärv, 2013). At the same time, the dark figure is probably high and the amount of research on minorites victimization experiences limited due to restricted access. The lack of research regarding hard-to-reach group's experiences of victimization in general and the Roma population in particular, we argue, results in a lack of knowledge about these groups, which contributes to the ongoing marginalization of those same groups.

The object of this article was therefore to seek to identify strategies for successfully studying ethnic minority groups, with a special focus on the Roma minority. Based on interviews with members of the Roma community we identity barriers related to gaining access to the population for research purposes and suggest strategies to overcome these barriers. We conclude with the argument that researching vulnerable groups is only possible if we develop an understanding of the complexities surrounding such groups, and how important this knowledge is for both carrying out research and implementing knowledge and preventive strategies. We begin with a brief description of the Roma minority to provide the reader with a background as to why this group may be a hard to reach group.

\subsection{One Label - Multiple Identities}

Within the literature and the political debate the Roma are described as a relatively heterogeneous group. However, in reality, the Roma is a culturally heterogeneous group. In Sweden, five subgroups are recognized within the national 
Roma minority: Swedish Roma, Travellers (in Swedish resande), Finnish Roma, Non-Nordic Roma and Newly arrived Roma. These subgroups have largely distinct cultures, linguistic dialects, cultural attributes (such as choice of clothing, religion and traditions), historical background and perception of their own ethnicity and identity. An alternative classification based on self-identification could be that a person thinks that he or she belongs to subgroups named Kalderasha, Lovara, Churarara, Bergitka, Kalé, Resande, Sinti etc. The classification follows the language variants but also goes across national boundaries. It has sometimes been discussed among Roma and non-Roma whether groups such as "Sinti" in Germany and Austria, "Traveller" in the UK or "Travellers/Resande" in Sweden should really be classified as Roma (see for example Lindholm, 1995). According to Hancock (2010), various Roma subgroups often have relatively weak social and cultural ties to each other and it is not uncommon for one group to consider another group to not be "real Roma". These differing views on ethnicity and identity can probably be explained from a historical perspective: Roma have been isolated from each other and therefore developed in different directions culturally.

\subsection{Roma in Sweden and in Europe - History of Oppression}

The Roma are believed to have emigrated from northern India in the 900's or 1000's, the sources of Roma history are however few and causes of emigration and if the group emigrated in one ore in several waves is unclear (McGarry, 2010). From the beginning the Roma was well received and settled themselves in Eastern and Central Europe. From the 1450s and onwards the Roma were accused of being Turkish spy's and engaging in witcheraft, which according to many researchers caused the group to become stigmatized (Hancock, 2010; McGarry, 2010). From the sixteenth century, countries such as Denmark, England, France, Germany, Italy, the Netherlands, Norway, Scotland, Sweden, and Switzerland passed various laws that made it illegal for some Roma to cross their borders (Pertova, 2003). Additionally, another Roma group (usually called "Vlax- Roma") became slaves in the east, most notably in the territory that is Romania today (Hancock, 2010).

During the Holocaust, the Roma together with the Jews were most severely affected (Hancock, 2010). At the same time a political debate arose in Sweden about the "tinker plague", which led to a state interest in identifying Roma in the Swedish population. In parallel with several initiatives to register the Roma, the group was also subject to a number of officially sanctioned human rights abuses including forced sterilizations, the forced removal of children, housing prohibition and exclusion from the education system (SOU, 2014).

As a consequence of this historical oppression it is often asserted that the Roma live a marginalized existence and has due to this lost many cultural manifestations. Since many of the atrocities were committed by authorities it is common among Roma today to lack confidence in the majority society in general and the criminal justice system and other state authorities in particular. It should be pointed out that it is problematic to describe Roma history and current situation in a single framework. The various subgroups often have different historical experiences and as a consequence different current situations (SOU, 2010). Today, it has been estimated that about 50,000 Roma live in Sweden (SOU, 2010), however, this estimate should be viewed as uncertain, since ethnic registration is not conducted in Sweden.

\subsection{Racism, Discrimination and Anti-Roma Hate Crime Today}

Today, the Roma are marginalized in several areas, such as employment, education, housing and health, and their situation is on average significantly poorer than that of non-Roma living in the same countries (European Union Agency for Fundamental Rights, 2012; SOU, 2010). Roma people themselves think of Sweden as a racist country where they are neither accepted nor welcome. They experience hostility and many are called derogatory names on a regular basis (Forsberg \& Lakatos, 2003). In a survey carried out by the Swedish equality ombudsman (DO), one third of the Roma respondents reported having been denied to buy or rent housing because of their ethnicity (Ombudsmannen mot etnisk diskriminering). The stigma attached to the Roma minority may, apart from leading to discriminatory practices, affect people's well-being. Research indicates that many adopt dual identities, one private identity and one public identity where their group belonging, whether it concerns sexuality or ethnicity, is concealed (Convery \& O'Brian, 2012). The Swedish Delegation for Roma Issues has concluded that the Roma are excluded from mainstream society by means of a solid pattern of social, economic and political marginalization (SOU, 2010). It should however be noted that the various Roma subgroups often describe their current situation differently. For example, Travellers currently live a relatively integrated life in Sweden (SOU, 2010). The Travellers differ from the other subgroups as they often claim to have lost much of their culture and have a weaker political position and less influence than other Roma subgroups (SOU, 2010; Hazell, 2011). The other subgroups draw more attention to their poorer socio-economic status in relation to the majority society (Westin et.al. 2014). However, it is common for the different subgroups within the national Roma minority to draw attention to everyday discrimination, racism and anti- gypsyism as a problem in Sweden (SOU, 2010).

If we view discriminating and marginalizing practices on a continum, violent crimes motivated by hate toward the group that the victim presumably belongs to would represent the more extreme form of discrimination (Perry, 2001).

Hate crime victimization, in addition to the traditional harmful effects of crime, can lead to a situation in which minority 
groups become stigmatized and experience further difficulties in improving their position in mainstream society. Hate crimes differ from other crimes, mainly in the aspect that the act is damaging not only to the direct victim but creates fear and marginalizing for whole groups (e.g. Perry, 2009).

The prevalence of hate crimes against ethnic minorities remains relatively unexplored (Heber, 2007), with a few exceptions (e.g. Wigerfelt, Wigerfelt \& Kiiskinen, 2014). The extent of anti-Roma victimization is difficult to appreciate due to the large dark figure, but is assumed to be significant and on the rise (Aspling \& Djärv, 2013; European Union Agency for Fundamental Rights, 2009).

\subsection{Studying Vulnerable Groups}

Across Europe there are several hard-to-reach groups. As Europe becomes more culturally diverse, cultural understanding and competence become increasingly important for researchers in all fields as ethnic minorities have been found to be more difficult to contact and more likely to refuse participation in most part of social-science research (Couper \& Leeuw, 2003; van Goor et al, 2005). Kelly (2003) shows how contact with Bosnian refugees in Britain and access to the group was primarily established via community organizations and community leaders. Such strategies have been found to be successful in recruiting minority groups (Harachi et al., 1997), but as Kelly notes, the opinions held by community organizations do not necessarily reflect the whole communities views. Similarly, relying solely on community leaders, predominantly older males, gives a skewed picture of the individual opinions in the community (Rowe, 2004).

A question previously raised in relation to studying minorities is the role played by the researcher's cultural and/or racial identity as similar or different from the group being studied. The ethnicity of the researcher has been found to be of importance when working with minority groups (Senior \& Bhopal, 1994), both for gaining access to the group, to increase trust and for the utilization of results (Kosa \& Adany, 2007). Some argue that non-minority members can reliably study minority groups (Gelsthorpe, 1993; Dotinga, et al, 2005; McLean \& Campbell, 2003; Alexander, 2004; Gunaratnam, 2003) while others argue that only members of minorities can study the like (Anderson et al, 1988). Belonging to one of two groups that has an ongoing conflict may also be an obstacle to access. Self-identified Muslim researcher Al-Natour from Australia set out to investigate a controversy among several thousand residents concerning a proposed Islamic school in a local neighbourhood. When recruiting residents to interview many denied being interviewed because of Al-Natours Muslim identity (Al-Natour, 2010, 2011).

Kosa and Adany (2007) raised the issue that non-minority members risk interpreting findings in a misleading way because of a lack of basic understanding of the issues faced by minorities. Others yet argue that outsiders can indeed carry out research but that members of the studied minority should be involved in every stage of the research process (Phillips \& Bowling, 2003; Kosa, 2007). Quraishi (2003, as cited in Garland, 2006), of south Asian parentage, studied Muslim prisoners of whom a majority was black Carribean. Quraishi drew on different aspects of his identity, racial and religious beliefs, depending on whom he interacted with. Spalek (2002) studied Muslim women wearing a Hijab and since she did not share the women's ethnicity and religious beliefs she instead emphasized her gender in order to gain access and build rapport. The cultural understanding perspective is closely related to that of power relations. In Spaleks example she is partly an insider as she shares gender position with the studied women, but as white she is an outsider. Garland et al (2006) stresses that a researcher at every stage of the research process must reflect on how his or her self-identity may affect the decisions taken and the interpretation of the results.

\subsection{The Present Study}

Based on interviews with members of the Roma community, this study examines the difficulties related to gaining access to the population for research purposes, and seeks to identify strategies for successfully studying ethnic minority groups. The lack of research regarding hard-to-reach group's experiences of victimization, we argue, results in a lack of knowledge about these groups, which contributes to the ongoing marginalization of that same groups.

Approaching a marginalized group such as the Roma is associated with several difficulties. Firstly, in Sweden there is no ethnic registration, and we lack knowledge about the actual size of the minority population. Also, the historical discrimination, segregation and stigmatization of the Roma across Europe have led many Roma to actively conceal their ethnicity. Combined, this makes it difficult to locate members of the group. Thus, the use of random sampling is not possible. Secondly, and as a consequence of the former, generally in the Roma community the level of confidence in the majority society is low (Hazell, 2011; SOU, 2010).

A prerequisite for the successful implementation of the present study was therefore to find an appropriate way not only to engage with the members of the minority, but also to get them to participate in interviews. One of the authors (S.W) is a member of and relatively well-known in one of the subgroups, the Traveller community, and as such had the opportunity to use existing networks to reach representatives of the Roma minority. 


\section{Method}

\subsection{Procedure}

Data was originally collected within a student thesis project and results have in part been published in Wallengren (2014). Five interviews were carried out with representatives of different Roma subgroups. In-depth, unstructured, interviews have been considered to be beneficial as the Roma subgroups are likely to have different opinions. The aim was to get access to unique experiences and thoughts about the social interaction between researchers and participants, from the perspective of the participants. Recognizing the differences between subgroups, the aim was to obtain a mix of the Roma population among the informants. We also wanted to capture a variety in terms of age and gender.

To achieve a variation of informants, we used non-probability snowball sampling. The snowball-sampling method is often employed when the target population is hard to reach, hidden or vulnerable (Atkinson \& Flint, 2004), such as homeless people (Shaw, Bloor, Cormack \& Williamson, 1996) and ethnic minorities (Hughes, Fenton, Pilgrim \& Tibbs, 1995).

It has been argued that informants may have greater confidence in the researcher if they have been approached by one of his or her acquaintances (Thomsson, 2002). Consequently, in a first step five acquaintances of one of the researchers were contacted. They were in turn asked to make suggestions of people who could be willing to be interviewed. This resulted in 24 suggestions; five were randomly selected and asked to participate in an interview. Three of them declined. We then randomly selected three more people and asked if they wanted to participate, and they did. The participants were informed about the study both verbally and in written, informed that participation was anonymous and that they could choose to terminate the interview at any time, or only answer parts of the questions. The interview was carried out at a place of the informants' choice. Interviews were carried out mainly in Swedish and the authors have translated all quotes.

\subsection{Participant Characteristics}

This section provides a brief description of the informants. Names have been changed and ages been adjusted in order to protect the identities of the informants. The informant's ethnicity is based on self-identity. Such a description of ethnicity does not say anything about how they are perceived by others. As pointed out before, the Roma group is heterogeneous and the umbrella concept "Roma" includes different subgroups with varying attributes. Recognizing this heterogeneity, rather than labeling all participants according to the official nomenclature, we label the participants after their own perceived identity.

We interviewed three women. The youngest informant is Romanita, a 19 year old woman who self-identify as a Traveller. Lovisa is a 35 year old woman who self-identifies as a Non-Nordic Rom. The oldest of the women is Kattinka who is 48 years old and self-identifies as Finnish Rom. Two men were interviewed, Eddvald who is a 54 year old Newly arrived Rom, and the oldest participant, Glegore who is an 80 year old self-identified Swedish Rom.

The interview data resulted in an extensive text material. In order to enable an analysis of the material, we searched for common patterns that could be linked to various key topics (Brinkmann \& Kvale, 2009).

\section{Results}

We identified several issues that from a Roma perspective were important obstacles, or rather prerequisites for a successful contact between the researcher and the Roma minority. These include establishing contact and getting access to the group, desired match between researcher and informant, the meaning of gender, age and language, cultural norms and asking sensitive questions. Results are presented as two main themes: Gaining access and Cultural competence.

\subsection{Gaining Access}

The informants were asked about how researchers, in their opinion, should go about making contact and gaining access to the group for research purposes, when asking sensitive questions on criminality and victimization.

The informants all agreed that a prerequisite for gaining access is to gain trust within the community. One way of achieving this is to go through organizations or being referred by someone. "I think the best way is to contact the organizations, those who work in them often have good confidence from the Roma community ", Eddvald said. " Lovisa " agrees:

"Contact organizations or other people who are known to the Roma, then it might go well; you could never make contact with the Roma yourself when they do not trust you. It is also important to address a variety of family representatives, I believe, and that you are careful to explain what you want to do, not wanting to harm the group".

It would be very difficult to reach Roma by contacting schools, churches or other institutions. This is mainly due to a fear of being registered, stemming from government agencies misuse of Roma registers. In 2013, the newspaper Dagens 
Nyheter revealed that the Swedish police had a secret "Roma register" which included thousands or Roma, even children and deceased. The revelation caused public outrage and probably further damaged Romas confidence in the criminal justice system. "Eddvald", "Kattinka", "Lovisa" and "Glegore" all expressed that the Roma would feel registered if one were trying to reach Roma by official institutions, which are not primarily targeted at Roma.

Due to fear of registration, several participants believe that many Roma actively hide their ethnicity. "Romanita" says, "almost no Travellers are open about their ethnicity and especially not where buron (none-Roma, authors note) have all the power". Since it is illegal in Sweden to register people by ethnicity, not being open with your ethnicity makes it more difficult to sample a group of Roma for research purposes. "Eddvald" also points out that Roma are absent from many institutions:

"You cannot find Roma in such places. Roma does not go to church that way, although we are very religious, few Roma educate themselves. I really do not think I've met any Rom that has been in college before. Very many Roma are unemployed, almost everyone I know here in Malmo and in their workplace, and they would never say that they are Roma, they would fear losing their jobs".

\subsubsection{Matching Interviewer and Informant}

Regarding ethnically matched interviewers the informants' positions differed. Those in favor of ethnically matched interviewers argued that "we know each other's afflictions", with a shared history, knowledge of the culture and an understanding of the everyday discrimination that many Roma experience. "Lovisa", 35 years says:

\section{"It should be a Roma that interview a Roma person, what do gadjo (none-Roma) know about us? Nothing!"}

"Lovisa" continues to explain that cultural understanding is important and that many Roma feel that their culture and customs will be contested over and analyzed when meeting non-Roma people.

When you meet a non-Rom they ask a lot of stupid questions about how it is to live as Rom, as we are some exotic animals to be explained. I do not want that, sometimes it feels insulting. When I was interviewed before, a bunch of girls came, they could not behave and I could tell that they felt so scared to be here with us. It felt awkward; I felt as if I had to take care of them"

"Glegores" experience is similar to "Lovisas": "I have been interviewed thousands of times in my life, Im tired of it. Often, a researcher who has a nice education and who has written books, you feel happy and think there must be something good about it. But when they start one begins to discover that they do not understand anything and they ask such stupid questions.

"Glegore" adds that it is important that a Rom analyzes the material, otherwise, he argues, there is a risk of misinterpreting the results. Also, The worst is when you then read what they have written; sometimes it's so terribly wrong that I am ashamed that I have participated..." ("Glegore").

However, "any Roma" could not conduct interviews. "Glegore", points out that "all Roma are not the same." "Lovisa" argues that Roma from the same or almost the same subgroup should conduct interviews.

"All Roma are not suitable. Both you Travellers (referring to the interviewer S.W., authors note) and the Finnish Roma are not quite the same as us (none-Nordic Roma, authors note). I think it would be difficult for you to interview and study the real Roma. I hope you do not take offense, but it is a fact that we have not really perhaps, always trusted each other..."

The youngest of the informants, "Romanita", shared the opinion that not any Roma would be allowed to carry out interviews. She expresses concern about the umbrella term "Roma". For example, her own group (the Travellers) do not, according to her, consider themselves to be Roma, and therefore it would be wrong to study them as Roma.

"One cannot study 'Roma'; this Roma term is actually something new. We real Travellers do not think of ourselves as Roma after all. Gypsies do not perceive us as Roma but tinkers. I would not participate in a study if it was not about the Traveller community and I think that almost nobody would... "("Romanita").

Representatives from the different Roma groups do not fully agree on this issue. "Kattinka" for example expresses the opposite from "Glegore", "Lovisa" and "Romanita". She doubts that members of her Roma subgroup, the Finnish Roma, would like to be interviewed by other Roma, especially from members of the same subgroup. "You do not talk about everything in our culture, they would not open up to another Rom. If you want to interview a Finnish kale (Finnish Roma, authors note) it is better to get a Swede to conduct the interview..."

\subsection{Cultural Competence}

Under the theme cultural competence several important aspects were identified, including rules for interaction within the Roma community, rules between the sexes, and what questions may be sensitive to ask, either due to a specific 
cultural belief or the groups history of oppression.

\subsubsection{Rules for Interaction}

Rules for interaction, often unwritten, are present in all cultures and help individuals coordinate their behavior and make socializing easier. Most importantly, they differ between societies. Breaking these rules, or not understanding or respecting them may cause fraction in the meeting between cultures (Weyrauch, 1997). "Romanipha/romanopha" or "rommanot", which roughly translates to the "Roma way" or the "Roma culture", is a set of rules for social interaction within the Roma community. The rules concerns, among other things, how one should behave when meeting the elderly, when interacting with someone of the opposite sex and how different behaviours are viewed as pure and others as polluted. As a researcher, having knowledge about these rules, abiding to them and respecting them may be critical for how you are received, and for gaining the participants trust, thus affecting the research results. In the interviews it became clear that how these rules are interpreted and applied differ between different Roma subgroups, demanding an even higher degree of context sensitivity from the researcher. Also, when conducting research on vulnerable groups the researcher should always make sure that the informant feels safe (Thomsson, 2002). On this issue, "Glegore", says:

"You must understand that such things are important if we Gypsies should feel safe, it is important to follow our rules when you are with us. Otherwise, you get no respect from us and no confidence. It is certainly difficult for many gadjo (non-Roma) to understand this, but it is very important".

An important aspect of romanipha/romanopha or rommanot is the distinction made between behaviour that is considered to be pure (vujo) and behavior that is considered polluted (marime). "Glegore" therefore emphasized being oriented on how to behave in relation to these types of behaviours as important. To some Roma, it is believed that a marime behavior can result in both sickness and death but also "moral uncleanness" which causes negative consequences for the individuals involved. For example, as a researcher conducting an interview with a Rom it may be impolite to shake hands when you meet, and for many Roma even insulting with such physical contact. Implying that you are about to conduct impure behaviour, such as going to the toilet, is also considered inappropriate (marime) to some.

"Glegore" elaborated on the rules for interaction. "If you do not know these rules you do not know how to cook food for a Roma, that one should not sit in certain places or how you should behave towards the elderly. You would never shake hands with me right? (The interviewer, identified as a Traveller, respond "No") no, because I'm the elderly. It's about respect and behavior. Simply - you do not say "Can I use your bathroom," you should say "I would like to wash my hands, " yes... If you want to get gypsies respect, it is important to respect this..."

The importance of following all the rules, however, vary between the informants. Most agree that it is important to, as "Eddvald" says, "... recognize some ground rules and respect each other" and as "Romanita" says "it's important to respect the older ones in our culture, but so does the buro (non-Rom, authors note), just in a different way".

Depending on age, everyone may not agree on the importance of following the rules. "Lovisa" says:

"It is important with these rules, but sometimes I think the older are exaggerating. I mean, most of us know what it's like to hang out with gadjo (non-Roma, authors note). They do not have these rules and it is often good anyway, you Travellers do have not the same rules but it is good nonetheless. I think primarily it is about being respectful".

There are also rules for interaction between men and women, which has direct implications for how to conduct face-to-face interviews. "Glegore", "Lovisa" and "Eddvald" said that men and women of the same age could not associate freely with each other.

"There are lots of rules for how men and women can socialize - in my and many other Roma cultures a man and a woman cannot sit alone together in the same room. This I suppose is important to note for you who want to know if you can do interviews with us ..." ("Kattinka")

For this reason, two of the three female informants, "Lovisa" and "Kattinka", had other people present when the interviews were conducted (author S.W. who conducted the interviews is male). Otherwise, they argued, they would not have been able to participate in the interview.

\subsubsection{Language Problems and Illiteracy}

Another issue that faces researchers conducting studies with members of the Roma minority is language problems and illiteracy. This may have ethical implications concerning fully informed concent, in particular when the questions asked are of a sensitive nature. "Eddvald" and "Lovisa" says that in their subgroups, Newly arrived Roma and non-Nordic Roma, there are "...many who cannot speak Swedish, and many of them are also illiterate..." This is something that "Glegore" also talks about and that may in part be explained by the historic discrimination of Roma in Sweden.

"Although we Swedish Roma have been here in Sweden for quite some time, many of us still have language problems 
because we were not allowed to go to school until the 70s. There are also many of us who have trouble with reading and writing ... it is possible to interview us in Swedish, but you must be vigilant in ensuring that everyone understands. "

"Eddvald" and "Lovisa" stressed that it would not be possible to conduct interviews with newly arrived Roma and none Nordic-Roma solely in Swedish. It is beneficial if someone speaks his or her dialect of Romani Chib or a Balkan dialect. However, the preferred language is not the same across groups. "Kattinka" says that the Finnish Roma cannot be interviewed in Romani chib:

"Almost no Finnish Roma speak Romani today, in addition, our dialect is so meager that it would not be feasible. You may use Swedishor Finnish to interview us. Many elderly Finnish Roma speak Finnish as their first language and many of the young also speak Finnish as their first language ... many Finnish Roma cannot read, it's important not to make them feel stupid. "

"Romanita", on the other hand, says that her group should be interviewed in Swedish. She also points out that illiteracy is a smaller problem in her particular subgroup, the Travellers.

"The Travellers have lived here for 500 years, we speak fluent Swedish. There might be some advantages to allow the elderly throwing in some Romani words here and there, you know "mander's really matto andivus, do you want a little mustan? (Authors translation: I am very tired today, would you like some coffee?)", Maybe it can make them a little more talkative but not more than that... "

\subsubsection{Asking Sensitive Questions}

According to "Glegore" it is not possible to study Romas victimization experiences. The topic is considered too sensitive, partly because of a strong and pronounced fatalism: "I do not really think you can ask Roma these questions you now ask me, no real Roma in each case. We Roma are superstitious and there is a certain thinking of the Roma that if you talk about it, it will also happen. We simply fear fate. "

"Romanita" and "Kattinka" disagree and instead argue that it on the contrary is possible to access groups and conduct studies on victimization experiences. But, they argue, this question is closely related to the one of ethnic matching. To ask sensitive questions requires that the researcher him or herself belong to the Roma group and have the necessary network of contacts trust within the community. They also talked about the importance of getting older representatives included in the work, as they will give the researcher a legitimacy, greater power and influence within the group. "Romanita" who self-identifies as a Traveller says:

"Crime victimization is sensitive; you can imagine that it is difficult for anyone to answer such questions. But if you belong to the right family or make contact with the older family representatives, it is increasingly possible to reach out to them, but I think you have to get the support of the older otherwise they will not participate. I would also point out that you couldn't turn to the organizations as they mainly focus on Roma or have very few Travellers there. "

All five respondents agreed that studying Roma's own criminality through interviews would be almost impossible "Glegore" said: Gypsies and tinkers would never answer questions concerning our own criminality, the issue is too sensitive. You would be kicked out if you asked about that. Gadjo (none-Roma, authors note) think of Roma as criminals all the time ... "Kattinka" says:

"I would not like that someone came to me and asked about Roma crime, it would be extremely offensive. Firstly, you cannot come into someone else's home and accuse them of these kinds of things; secondly, we are not more criminal than others. Every time I go into a store they are looking to see if I am stealing, which I don't do. No Roma would agree to an interview with such a discussion."

The female informants and one of the male informants also believe that it is not appropriate to ask questions about sexual victimization. Both because sexuality is a sensitive topic within the Roma culture but also because it is "unnecessary" and questions the Roma women's honor. "Romanita" says:

"Talking about rape and such do not make sense. I do not think it's appropriate to talk about these things at all".

It may also be considered sensitive or inappropriate to gather some of the background information often used in social science research. This information is often viewed as unproblematic within the research community in general, such as place of residence, income, family relations and having children or not. There were several explanations offered for why such information may be sensitive to ask. "Glegore" says, "it is sensitive to talk about deceased parents, or if they lack contact with any of them." "Kattinka" also believes that the Roma belonging to her own group (Finnish Roma) do not want to be asked about whether they have children or not because it reveals sexual behavior.

"In the Finnish Roma culture we do not talk about whether we have children or not. I do not know if you know this, but the children don't call their biological parents mother and father, as this signals that the two adult persons have had sexual intercourse. My culture is perhaps the most sensitive regarding sexuality, but it is important to respect this ". 
Questions about children can also be sensitive given the history of forced sterilization. It is not necessarily sensitive to ask younger individuals though, says "Romanita".

"You do not ask the elderly if they have any children or not, they might have been sterilized and then it's extremely sensitive, it may also be sensitive if it is the case that someone is a bit older, like 30-40 and do not have children because having a family is so important in our culture ".

\section{Discussion}

The Roma minority is a diverse community, officially referred to by the umbrella term Roma. This may lead to perceived, but false, homogeneity, with potential consequences for how the groups are approached. The interviewees Eddvald, Glegore, Romanita, Lovisa and Kattinka all represent different subgroups within the Roma minority in Sweden. We set out in this study to take on a different perspective. Instead of making our own reflections on the process of studying vulnerable groups the center of attention we wanted to focus on the informants' perspective. By interviewing individuals from different groups we have been able to demonstrate differences as well as similarities on issues any researcher interested in minorities should consider and methodological obstacles to take into consideration when planning and conducting a study and interpreting the results.

We identified several issues that must be considered when engaging in research on vulnerable and marginalized groups. Some are specific to the Roma community but we argue that the same sensitive and reflexive approach must be taken towards any group and findings have important implications for future studies of vulnerable minority groups.

An issue that we came back to several times during the interviews and that relates to most of the necessary considerations is the researchers position as an outsider or insider in relation to the studied group. How this position influence the research has been much debated in academia (Al-Natour, 2011). From a minority perspective, the identity of the researcher is important, and the status as insider or outsider in relation to the group being studied may affect the planning, conducting, and interpretation of the results (Zempi \& Chakraborti, 2014). For long it has been assumed that a researcher who occupies the opposite position from the person or group being studied is considered an outsider, presumably leading to difficulties in gaining the persons or groups trust (Young, 2004). These discussions have focused on the categories of sex, race and ethnicity, while today, the intersectionality of identities that one person has, has begun to be recognized. This opens for the possibility of a researcher to be both insider and outsider along the categories of sex, race and ethnicity but also when it comes to sexuality, education and class. Leaving the simple categorizations of race and sex put greater demands on researchers to consider their own position in relation to the studied group. In a sense "We are never truly outsiders, yet never wholly insiders either; however, we are always partial in examining our research results" (Al-Natour, 2011).

The informants in this study hold different views on the question of matching and whether the researcher should be an insider or outsider, according to what characteristics and how it affects the rapport building. Some argue that, from a cultural understanding perspective, only Roma can study Roma, and preferably "real Roma". "Real Roma" in this context is defined from the informants' perspectives as a person belonging to the same subgroup and may thus differ depending on who is doing the defining. Others argue, from the same perspective, that the researcher should be an outsider in some respects since a Rom would never discuss sensitive topics with another Rom. In terms of gender, matching is preferred and in some cases a prerequisite for the interview to take place, regardless of topic discussed. The person who conducted the interviews (author S.W.) for the present study is self-identified as a male Traveller and has due to his contacts within the minority group gained access and been able to recruit informants. As such he occupied a position whereby he was assumed to have "insider status". In the broad umbrella category, he is a Rom. However, as a young educated male, with a "Traveller" background, the status was also at times an "outsider". The characteristics that were shared with the informants in terms of social class, being from the Roma minority, and sharing some broad cultural similarities were side by side with differences including religious beliefs, historical and migratory background and linguistic skills. Some respondents pointed out that the group the interviewer represented was not considered "real Roma" and although it was more "Roma" than "non-Roma", Travellers, some argued, lack cultural understanding of the other groups. As a man, the interviewers access to female informants was also limited.

\section{Conclusion}

The results have implications for the relations between the majority population and minority groups in Sweden. It offers unique insight into a hard to reach community and shows that research is in fact possible but that it requires the researcher to engage with the community, to gain cultural understanding and competence and respect for the group that is to be studied.

Problems accessing a group for research purposes may result in a lack of research leading to a knowledge gap concerning some groups lived experiences whether it is about crime, victimization, health care or other issues facing 
minorities. Therefore, when approaching marginalized groups we may need to develop new techniques and adapt current methods. There is otherwise a risk that a group that is hard to reach also becomes easy to ignore.

\section{References}

Alexander, C. (2004). Writing race: ethnography and the imagination of the Asian gang. In Bulmer, M., \& Solomos, J. (Eds.), Researching Race and Racism Social Research Today, 134-139. London: Routledge.

Al-Natour, R. J. (2011). The Impact of the Researcher on the Researched. M/C Journal, 14(6), Retreived from http://journal.mediaculture.org.au/index.php/mcjournal/article/view/428

Al-Natour, R. J. (2010). Folk Devils and the Proposed Islamic School in Camden. Continuum, 24(4), 573-85. http://dx.doi.org/

Anderson, B. A., Solver, B. D., \& Abramson, P. R. (1988). The Effects of the race of the Interviewer on Race-Related Attitudes of Black Respondents in SRC/CPS National Election Studies. Public Opinion Quaterly, 52(3), 289-324. http://www.jstor.org/stable/2749073

Aspling, F., \& Djärv, C. (2013). Hatbrott 2012 (Report 2013:16). Stockholm: Brottsförebyggande rådet.

Atkinson, R., \& Flint, J. (2004). Snowball Sampling. In M. S. Lewis-Beck, A. Bryman \& T. Futing Liao (Eds.), The SAGE Encyclopedia of Social Science Research Methods, 1044-1045. http://dx.doi.org/10.4135/9781412950589.n931

Brinkmann, S., \& Kvale, S. (2009). Den kvalitativa forskningsintervjun. Lund: Studentlitteratur

Bonevski, B., Randell, M., Paul, C., Chapman, K., Twyman, L., Bryant, J., \& Hughes, C. (2014). Reaching the hard-to-reach: a systematic review of strategies for improving health and medical research with socially disadvantaged groups. BMC Medical Research Methodology, 14, 42. http://dx.doi.org/10.1186/1471-2288-14-42

Couper, M. P., \& De Leeuw, E. D. (2003). Nonresponse in cross-cultural and cross-national surveys. In J. A. Harkness, F. J. R. Van de Vijver, \& P. P. Mohler (Eds.), Cross-cultural survey methods, 157-177. Hoboken, NJ: John Wiley.

Convery, I., \& O`Brian, V. (2012). Gypsy-Traveller narratives: Making sense of place. Narrative Inquiry, 22(2), 332347. http://dx.doi.org/i0.i075/ni.22.2.07con

Shaw, I., Bloor, M., Cormack, R., \& Williamson, H. (1996). Estimating the prevalence of hard-to-reach populations: The illustration of mark-recapture methods in the study of homelessness. Social Policy and Administration, 30 (1) 69-85.

Ombudsmannen mot diskriminering. Diskriminering av Romer i Sverige. Rapport från DO:s projekt åren 2002 och 2003 om åtgärder för att förebygga och motverka etnisk diskriminering av Romer. Retrieved from, http://www.do.se/Documents/material-gamla-ombudsman/romarapportensv05.pdf

Dahl, U. (2005). Från hatbrott och homofobi till heteronormativitet och intersektionalitet. En kunskapsinventering och situering av forskning. Stockholm: HomO and Forum för levande historia.

Dickson-Swift, V., James, E. L., Kippen, S., \& Liamputtong, P. (2007). Doing sensitive research: What challenges do qualitative researchers face? Qualitative research, 7(3), 327-353. http://dx.doi.org/10.1177/1468794107078515

Dotinga, A., Van de Eijnden, R. J. J.M., Bodbeld, W., \& Garretsen, H. F. L. (2005). The Effect of Data Collection Mode and Ethnicity of Interviewee on Response Rates and Self-Reported Alcohol use among Turks and Moroccans in the Netherlands: An experimental Study. Alcohol and Alcoholism, 40(3), 242-8. http://dx.doi.org/10.1093/alcalc/agh144

European Union Agency for Fundamental Rights (FRA). (2009). Data in focus report 1: The Roma. European Union Minorities and Discrimination Survey (EU-MIDIS). http://fra.europa.eu/sites/default/files/fra_uploads/413-EU-MIDIS_ROMA_EN.pdf

European Union Agency for Fundamental Rights (FRA). (2012). The situation of Roma in 11 EU Member States Survey results at a glance (EU-MIDIS).

http://fra.europa.eu/sites/default/files/fra_uploads/2099-FRA-2012-Roma-at-a-glance_EN.pdf.

Ford, E. S., Bergmann, M. M., Boeing, H., Li, C., \& Capewell, S. (2012). Healthy lifestyle behaviors and all-cause mortality among adults in the United States. Preventive Medicine, 55(1), $23-27$. http://dx.doi.org/10.1016/j.ypmed.2012.04.016

Forsberg, A., \& Lakatos, A. (2003). Romernas Upplevelse av diskriminering i Sverige. Stockholms Universitet: Institutionen för socialt arbete. 
Garland, J., Spalek, B., \& Chakraborti, N. (2006). Hearing lost voices. Issues in researching 'hidden'minority ethnic communities. British journal of criminology. 46, 423-437. http://dx.doi.org/10.1093/bjc/azi078

Gelsthorpe, L. R. (1993). Approching the Topic of Racism: Transferable Reaerch Strategies? In D. Cook and B. Hudson (Eds.), Racism and Criminology, 77-95. London: Sage.

Gunaratnam, Y. (2003). Researching "Race” and Ethnicity: Methods, Knowledge and Power. London: Sage.

Hancock, I. (2010). Danger! Educated gypsy. Selected essays. Hertfordshire: University of Hertfordshire Press.

Harachi, T. W., Catalano, R. F., \& Hawkins, J. D. (1997). Effective recruitment for parenting programs within ethnic minority communities. Child and Adolescent Social Work Journal, 14, 23-39. http://dx.doi.org/10.1023/A:1024540829739

Hazell, B. (2011). Resande Folket - Från tattare till traveller. Stockholm: Ordfront förlag AB.

Heber, A. (2007). Var rädd om dig! Rädsla för brott enligt forskning, intervjupersoner och dagspress (Dissertation). Stockholm: Stockholm University.

Higgins, I. (1998). Reflections of conducting qualitative research with elderly people. Qualitative Health Research, 8 , 858-66. http://dx.doi.org/10.1177/104973239800800610

Hughes, A. O., Fenton, S., Hine, C.E., Pilgrim, S., \& Tibbs, N. (1995). Strategies for sampling black and ethnic minority populations. Journal of Public Health, 17(2), 187-92.

Kalaydjieva, L., Morar, B., Chaix R., \& Tang, H. (2005). A newly discovered founder population: the Roma/Gypsies. Bio essays, 27, 1084-1094. http://dx.doi.org/10.1002/bies20287

Kósa, K., \& Ádány, R. (2007). Studying vulnerable groups. Lessons from the Roma minority. Epidemiology and society, 18(3), 290-299. http://dx.doi.org/10.1097/01.ede.0000258919.15281.4f

Kelly, L. (2003). Bosnian refugees in Britain: questioning community. Sociology, 37, 35-49. http://dx.doi.org/10.1177/0038038503037001386

Lindholm, G. A. (1995). Vägarnas folk De resande och deras livsvärld. Etnologiska föreningen i Västsverige Göteborg.

Lindgren, M. (2004). Brottsoffer i rättsprocessen: Om ideala brottsoffer och goda myndigheter (Dissertation). Stockholm: Stockholm University.

McGarry, A. (2010). Who Speaks for Roma? Political Representation of a Transnational Minority. New York and London: Continuum.

McLean, C. A., \& Campbell, C. M. (2003). Locating Research Informants in a Multi-ethnic Community: Ethnic Identities, Social Networks and Recuitment Methods. Ethnicity and Health, 8, 41-61. http://dx.doi.org/10.1080/13557850303558

Naples, N. (1996). A Feminist Revisiting of the Insider/Outsider Debate: The 'Outsider Phenomenon' in Rural Iowa. Qualitative Sociology, 19(1), 83-106. http://dx.doi.org/10.1007/BF02393249

National Union of Students, NUS. (2011). Hate Crime, Interim Report - exploring students' understanding and experiences of hate incidents. National union of students. Retreived from http://www.nus.org.uk/Global/NUS_HateCrimeReport_web.pdf

Perry, B. (2009). There's just places ya don't wanna Go: The segregating impact of hate crime against Native Americans. Contemporary Justice Review: Issues in Criminal, Social, and Restorative Justice, 12(4), 401-418. http://dx.doi.org/10.1080/10282580903342888.

Perry, B. (2001). In the name of hate: understanding hate crimes. New York: Routledge.

Phillips, C., \& Bowling, B. (2003). Racism, ethnicity and criminology: developing minority perspectives. British journal of criminology, 43(2), 269-290. http://dx.doi.org/10.1093/bjc/43.2.269

Petrova, D. (2003). The Roma: Between a myth and the future. Social Research, 70(1), 111-161.

Rowe, M. (2004). Policing, Race and Racism. Devon: Willan.

Senior, P-A., \& Bhopal, R. (1994). Ethnicity as a variable in epidemiological research. British Medical Journal, 309(6950), 327-330. http://dx.doi.org/10.1136/bmj.309.6950.327

Sin, C. H. (2007). Ethnic-matching in qualitative research: Reversing the gaze on 'white others' and 'white' as 'other'. Qualitative Research, 7(4), 477-99. http://dx.doi.org/10.1177/1468794107082304

Smith, J. A. (1996). Beyond the divide between cognition and discourse: using interpretative phenomenological analysis 
in health psychology. Psychology \& Health, 11(2), 261-271. http://dx.doi.org/10.1080/08870449608400256

SOU (2014). Den mörka och okända historien - Vitbok om övergrepp och kränkningar av romer under 1900-talet. Stockholm: Fritzes offentliga publikationer

SOU (2010). Romers rätt - en strategi för romer i Sverige. Stockholm: Fritzes offentliga publikationer

Spalek, B. (2002). Muslim womens safety talk and their experience in victimization. In Spalek, B. (Ed.), Islam, crime and criminal justice, 50-75. Cullompton. Willan.

Thomsson, H. (2002). Reflexiva intervjuer. Lund: Studentlitteratur.

Triffleman, G., \& Pole, N. (2010). Future directions in studies of trauma among ethnoracial and sexual minority samples. Journal of Consulting and Clinical Psychology, 78(4), 490-497.

Tyler, T. R. (2001). Public trust and confidence in legal authorities: what do majority and minority group members want from the law and legal institutions? Behavioral Sciences \& the Law, 19(2), 215-235. http://dx.doi.org/10.1002/bsl.438

Van Goor, H., Jamsma, F., \& Veenstra, R. (2005). Differences in undercoverage and nonresponse between city neighbourhoods in a thelephone survey. Psychological Reports, 96, 867-78. http://dx.doi.org/10.2466/pr0.96.3.867-878

Walklate, S. (2008). Researching victims. In R. King, R., \& Wincup, E. (Eds.), Doing research on crime and justice. Oxford: Oxford university press.

Westin, N., Wallengren, S., Demiter-Taikon, K., \& Wesin, C (2014). Antiziganism i statlig tjänst: Socialstyrelsens behandling av romer och resande under 1900-talet. Stockholm: Socialstyrelsen.

Weyrauch, W. (1997). Gypsy law: Romani legal traditions and culture. Berkeley: University of California press.

Wigerfelt, A., Wigerfelt, B., \& Kiiskinen, J. (2014). When Colour Matters: Policing and Hate Crime. Social Inclusion, 2(1), 1-11. http://dx.doi.org/10.17645/si.v2i1.31

Young, A. (2004). Experiences in Ethnographic Interviewing about Race. In Bulmer, M., \& Solomos, J. (Eds.), Researching Race and Racism, 187-202. London: Routledge.

Zempi, I., \& Chakraborti, N. (2014). Islamophobia, Victimisation and the Veil. Palgrave Macmillan.

\section{(cc) $\mathrm{Br}$}

This work is licensed under a Creative Commons Attribution 3.0 License. 